\title{
German Economic Performance: Disentangling the Role of Supply-side Reforms, Macroeconomic Policy and Coordinated Economy Institutions ${ }^{1}$
}

\author{
Wendy Carlin and David Soskice
}

June 2008

\begin{abstract}
Debate about Germany's poor economic performance following unification focused on supply-side weaknesses, and the associated reform agenda sought to make low-skill labour markets more flexible. We question this diagnosis using three lines of argument. First, effective restructuring of the supply-side in the core advanced industries was carried out by the private sector using institutions of the coordinated economy, including unions, works councils and blockholder owners. Second, implementation of orthodox labour market and welfare state reforms created a flexible labour market at the lower end. Third, low growth and high unemployment are largely accounted for by persistent weakness of domestic aggregate demand, rather than by failure to reform the supply side. Strong growth in recent years reflects the successful restructuring of the core economy. We also suggest how changes in political coalitions allowed orthodox labour market reforms to be implemented in a consensus political system.
\end{abstract}

\section{JEL: E65, J50, P52}

Key words: economic performance; economic reform; varieties of capitalism; collective bargaining; corporate governance; Germany; United Kingdom

\footnotetext{
${ }^{1}$ This paper draws on a body of related research including Carlin and Soskice (2007a, b), which has been presented to different audiences. Useful comments have been received from conferences at the Harvard Center for European Studies, LoWER in Amsterdam and the CEPR-ECB-Bank of Italy workshop at the EUI, Florence and from three anonymous referees. We have benefited from excellent research assistance provided by James Cloyne and Etienne Hans and from discussions about these questions with Andrea Boltho, Andrew Glyn, Bob Hancke and Matthew Harding. David Soskice acknowledges financial support from the Anglo-German Foundation.
} 
For the decade and a half following German unification, Germany's economic performance was poor. Throughout this period, debate among domestic and international analysts and policy-makers (e.g. the German Council of Economic Experts, the European Commission and the OECD) focused on the role of labour market rigidities and the need for reforms, with the objective of creating labour market flexibility in line with AngloAmerican norms. However, the contours of German performance pose some puzzles for this interpretation. In particular, effective restructuring of the supply-side in the core advanced industries has been carried out by the private sector using institutions of Germany's coordinated economy model, including unions, works councils and blockholder owners. This indicates the continuing value of the institutions of the coordinated economy to the private sector in the face of external pressures of increased global competition. And we argue that it helps explain Germany's strong external performance since the late 1990s. Second, orthodox labour market and welfare state reforms were implemented and created labour market flexibility at the lower end with an associated increase in wage dispersion and incidence of low-paid work. The combination of these two supply-side developments has sharpened the separation of the labour market in the advanced sector of the economy from the 'outsider' labour market. Third, the presence in Germany until 2005 of low GDP growth and high unemployment at the same time as low real wage growth relative to productivity points toward the role of persistent domestic aggregate demand weakness and is harder to reconcile with a supply-side causal mechanism. Moreover, implementation of reforms to make the labour market more flexible may have interacted with the behaviour of workers with specific skills to increase precautionary saving and contributed to depressed domestic demand.

Nevertheless, our alternative hypothesis itself raises puzzles. The first is economic: how can aggregate demand shocks account for unemployment outcomes that persist for over a decade? The second and third are political economic: if persistent weakness of domestic demand was at the core of Germany's poor performance, what accounts for the absence of stabilizing macroeconomic policy? And finally, how did a consensus political system as is characteristic of a coordinated economy secure support for labour market reforms that are associated with increased inequality and the polarization of the labour market?

A central problem with assigning an independent role to aggregate demand weakness in accounting for German economic performance is highlighted by the widely used New Keynesian macroeconomic model. In this model, a negative aggregate demand shock produces a temporary rise in unemployment and fall in inflation followed by a return to the pre-existing constant inflation equilibrium. Thus the observation of persistently high and rising unemployment alongside modest and stable inflation suggests deterioration on the supply side with no independent role for aggregate demand. However, extending the macroeconomic model to the open economy introduces a new channel through which aggregate demand shocks can produce persistent effects on unemployment. We suggest that this open economy channel, which we explain in Section 2, provides a way of reconciling Germany's depressed real wage growth with weak growth and employment in the context of negative demand shocks. To help illustrate the mechanism, we contrast Germany's experience with that of the UK, where positive demand shocks prevailed in this period. 
Germany suffered a series of adverse demand shocks including monetary retrenchment in 1993-4, fulfilment of the Maastricht conditions in 1994-9 and the oil price increase and external deflationary pressures of 2004-5. Long-lasting effects of reunification depressed growth through the 1990s via both demand and supply effects of the higher burden of taxation associated with financing unification and the deep and the protracted contraction of the German construction sector. German competitiveness declined following unification and export market shares fell until the latter part of the 1990s. Unlike a number of other OECD countries including the UK, house prices were stagnant or falling throughout the period, which prevented a housing-related consumption boom. In the light of these negative shocks to demand, a political economic puzzle is why Germany has been unable or reluctant to use stabilization policies? One obvious answer is that monetary policy is no longer available under EMU. Why then not use discretionary fiscal policy? The complementarities between institutions suggest that at the economy-wide level, the presence of large but non-encompassing wage-setters requires a nondiscretionary macroeconomic framework in order to create incentives for wage restraint. This may help to explain the absence of a stabilizing macroeconomic response in Germany in the face of persistently weak domestic aggregate demand especially in the post-2000 period: recovery from the end of 2004 rested entirely on the strength of external demand.

The second political economic puzzle stems from the consensus German political system and its relationship to the wage-setting institutions and vocational training arrangements. The heavy reliance of firms on deep firm- and sector-specific skills creates a role for union wage-setters located outside the firm. Union wage-setters are able to curtail the exercise of bargaining power by skilled insiders who would otherwise be able to extract rents from the firm with excessive wage demands. In turn, if workers are to invest in these co-specific assets, the welfare state has to provide adequate insurance in the event of job loss due to company failure (Iversen, 2005). This brings in the nature of the political system since the long-term character of the investments requires that institutional change be difficult and require wide agreement. Thus a consensus political system complements the other coordinated economy institutions. The framework of the Varieties of Capitalism (Hall and Soskice, 2001) literature with its emphasis on such complementarities faces a challenge in accounting for the introduction in Germany of wide-ranging reforms of the welfare state weakening protective labour market institutions. The specific characteristics of German partisanship and union structure have been proposed as ways of accounting for the inegalitarian character of the reforms implemented, and the reshaping of political coalitions which this has required.

In Section 1, we focus on the evolution of the supply side in Germany looking both at how the private sector used the institutions of the coordinated economy to undertake restructuring, and at government-led reforms designed to increase labour market flexibility. In Section 2, we compare the extended growth recession in Germany with the long recession-free boom in the UK. This allows us to illustrate how contrasting patterns of aggregate demand - positive shocks in the UK case and negative ones in the German case - are consistent with the divergent outcomes in unemployment and real wages observed. The role of the open economy channel is reflected in real exchange rate 
appreciation in the UK and real depreciation in Germany. We also draw attention to the likely difference in the macroeconomic effects of a restructuring process focused on reducing relative unit labour costs in a large economy like Germany as compared with a small open economy (such as the Netherlands). In Section 3, we turn to the political economic arguments, looking first at why German institutions may be especially illsuited to the use of discretionary macroeconomic policy and second, at how changes in political coalitions in Germany made possible the implementation in a consensus political system of reforms that weaken protective labour market institutions.

\section{The supply side in Germany: private sector restructuring and government reforms}

In spite of the emphasis on supply-side failure in much analysis of Germany's economic woes, there is evidence of robust restructuring in the core advanced sector of the economy and of the effects of labour market reforms in the 'outsider' labour market. Indeed, the functioning of the German labour market has changed substantially over the post-unification period. The outcome of the combined pressures from increased global competition in product and financial markets with deregulatory reforms produced a shrinkage of the insider labour market and a widening gap in wages and employment conditions between insider and outsider labour markets.

In the private sector, the insider labour market refers to employees in manufacturing, finance, insurance, and business services, in large firms, and on full-time permanent contracts. One indicator of the increased segmentation that has occurred is that whereas the prevalence of low-wage work among full-time employees in the core sectors hardly changed from 1995-2003, it increased sharply in smaller firms, in sectors outside the core, and in those affected by privatization (such as infrastructure and transport) or subject to competition from 'posted' workers from other EU countries employed under the home country's employment conditions (such as construction) (Bosch and Kalina, 2008, Table 1.6). A second indicator is the prevalence of temporary work. Among men, the change has taken Germany from below the EU-15 average in 1995 to above it a decade later. In 1995 the proportion of employees in temporary work was 9.9\% $(10.6 \%$ in the EU-15) and rose to $14.3 \%$ (14.0\% in the EU-15) by 2005 (OECD.Stat; Labour Force Statistics, 2008).

\section{Supply-side restructuring - the private sector and coordinated economy institutions}

We suggest that the very different type of labour market and skill organisation in Germany in comparison to the UK and the US has played an important part in the conduct of private sector-led restructuring of the past decade in Germany and may also help account for cross-country differences in consumption behaviour that came to the fore and that are discussed in Section 2. Of central importance in the argument is the vocational training system in which companies play a leading role, and in which young workers acquire relatively deep skills specific to a sector and to a considerable extent to a firm. Among full-time workers in Germany in 2003, three-quarters had a vocational qualification, $11 \%$ a college or university degree and $13 \%$ were unskilled (Bosch and Kalina, 2008, Table 1.2, p. 32). By contrast, the UK and the US place far more emphasis 
on general education and training with a correspondingly lower share of vocationally qualified workers and higher shares of both tertiary and unskilled workers.

Recent analysis using linked employee-employer data for 1997-2002 provides evidence that the German apprenticeship system is able to create incentives for companies to invest in human capital by providing costly general and occupation-specific skills in manufacturing and other sectors where deep company and industry skills are required. In sectors where training is costly for the training firms, post-training wage compression, and a thin outside labour market enhance the value of the match between training company and employee, allowing the investment to be recouped. In occupations where skills are more general and mobility is higher, the provision of apprenticeships is costneutral for training firms (Mohrenweiser and Zwick, 2008). In the past, such 'lower tier' apprenticeships - often in small firms - were the route to semi-skilled employment in the insider labour market (Soskice, 1994). One of the key questions for research is how the restructuring of the labour market has affected the employment outcomes of workers with these qualifications and how it will feed into the incentives for children in the education system. The depth of skills across the German work-force that arise from the apprenticeship system is illustrated by cross-country comparisons of labour quality. Estimates at industry level for the year 2000 comparing Germany, the US, the UK and France show Germany ranked first in all but 12 of the 68 industries (Mason et al., 2007).

The restructuring of the economy connected to the core labour system has been extensive and successful. Moreover, this has been carried out by private sector agents (unions, employers' associations, firms, works councils) without a direct role for the government. Restructuring has entailed increased consensus-based decision making in firms with works council chairs playing a greater role in co-management (e.g. Höpner, 2003). The median (i.e. skilled) employee interest has become increasingly aligned with the firm's. Whilst industry unions still play a major role in coordinated wage bargaining and vocational training, both have become more oriented to company needs (Thelen, 2007, Addison et al., 2007). Industry unions are more dominated than in the past by major works council chairs and in industries that are less unionized (e.g. banking and insurance), works councils have also played an important role in the restructuring of advanced service sector companies.

Key changes since the early 1990s include the collapse of coordinated bargaining in East Germany, where the attempt to reproduce the core German model largely failed. In West Germany smaller firms tended to leave the formal wage-setting system but small firm associations emerged to shadow coordinated wage bargaining since the reasons for not wanting internal firm-level wage-setting prevail. Union membership density (as a percentage of employees) fell from 32\% in 1980 to 23\% in 2004 (in West Germany; 18\% in East Germany). However, although coverage declined as well, in 2004 it was still the case that $68 \%$ of employees in West Germany and $53 \%$ in the East were covered by collective agreements and that for about one-half of those not covered, the sectoral agreement was the point of reference for wage-setting (Addison et al., 2007). There was also a shift in a range of tariff-related bargaining areas from union to company works council level (e.g. part-time working for older workers) negotiated with the unions and with input from works councils. 
Average job tenure appears not to have fallen, which suggests that companies have focused on internal restructuring and the flexible redeployment of workers facilitated by the new occupational profiles and flexible working times negotiated with unions (Bosch and Kalina, 2008). An important mechanism for internal restructuring has been companylevel pacts for employment and competitiveness (betriebliche Bündnisse zur Beschäftigungs- und Wettbewerbssicherung). Hassel and Rehder (2001) document such pacts in just under half of the largest 120 German companies. They were of three types: in the first, the objective was to redistribute work among employees. This entailed concessions from employees on the extent and flexibility of working hours and on labour mobility in exchange for guarantees of employment security and vocational training from employers. In the second type, wage concessions were granted in exchange for employment security and investment and in the third kind, productivity gains were secured by worker concessions on working hours, reductions in absenteeism and work reorganization in exchange for employer commitments on investment. Hassel and Rehder report that in only $10 \%$ of the companies, were the unions not involved in some way in the negotiations.

In the model of a coordinated economy, blockholder owners play a role both in allowing long-run relationships between workers and the firm to be sustained and in facilitating the monitoring of performance within the firm. Neither worker nor manager performance in these activities is easily evaluated in external markets and skilled workers need mechanisms to ensure that their investments in acquiring new competences will not be undermined by radical changes in asset use. The globalization of financial markets expanded the opportunities for owners of capital and increased the rate of return required by shareholders, putting pressure on companies to deliver 'shareholder value'. However, it appears that the blockholder ownership pattern has remained largely in place in Germany through this period of restructuring. New institutional owners have emerged but typically as minority holders. Management and works councils chairs were able to make use of the new institutional investors when they needed to apply pressure for the restructuring of companies.

Although the available data is fragmentary, a number of sources of evidence - on ownership, the presence of different kinds of institutional investors and the nature of changes in corporate governance at company level - support the hypothesis that under the pressure of the global integration of financial markets, Germany developed differently along these dimensions than Italy or France, and remains very distinct from the UK (Carlin, 2007). ${ }^{2}$ One indicator of the continued importance of blockholders is that the proportion of market capitalization owned by non-financial companies increased in Germany from 37\% in 1996 to $43 \%$ in 2004 and the share owned by financial institutions

\footnotetext{
${ }^{2}$ In Italy, control structures adapted to far-reaching changes in regulation in a way that reproduced preexisting control patterns (e.g. pyramids were replaced by shareholder coalitions) and protected incumbents from the growing threat of international competition. Corporate sector performance was poor. In France, there is evidence of transition toward a different institutional cluster: changes in regulation led to the replacement of blockholder arrangements by the greater engagement of activist institutional investors, including those from abroad (Carlin, 2007).
} 
declined from $21 \%$ to $15 \% .^{3}$ An analysis of voting blocks in German listed firms showed stability in the core companies and core sectors of the economy, with a modest move toward somewhat smaller blockholder stakes in firms (mainly in 'new economy' sectors) present in 2003 but not in 1997. In Germany like France, changes in governance standards toward greater transparency led to greater engagement of foreign and domestic institutional investors. However in Germany, such involvement appears to have been of a more passive kind: investors who were largely content with existing management and control arrangements sought to take advantage of opportunities for portfolio diversification, rather than taking stakes to gain active control. Goyer $(2006,2007)$ argued that foreign pension funds acquired small stakes in large firms in both France and Germany as part of their diversification strategies but that a clear difference in preference for stakes in French versus German firms could be observed in the case of mutual and hedge funds. The argument is that the latter favoured investment in France over Germany because of the greater unilateral control by top management in French firms, where works council involvement is absent. The changes in corporate governance and the functioning of the block-holder system in Germany fit the broader picture of restructuring from 'below' or 'inside', with government reforms having only a limited effect on how the core economy functions.

An important dimension of private sector restructuring by German companies has involved the reorganization of their production processes to make use of new opportunities for the sourcing of inputs from abroad. The rapid emergence of competitive locations for the supply of goods and services in Asia and in the transition economies of Central and Eastern Europe in the 1990s offered opportunities for German companies to improve their profitability. In tandem with the renegotiation of working practices and remuneration schemes at home using pacts for employment and competitiveness, operations abroad were expanded. A detailed exploration of the employment effects of the activities of German multi-national companies for 1999-2001 shows that those companies that expanded employment in their foreign affiliates retained more workers at home than otherwise similar German firms that did not expand employment abroad (Becker and Muendler, 2008). Since the expansion of foreign activities is integral to globalization, this test is much more informative about the impact of outsourcing on firm behaviour and employment than studies that look at the substitutability between home and foreign workers, holding output constant. Becker and Muendler found that German firms expanding their activities abroad (in any foreign location) had higher retention rates (than firms that did not expand) for workers with high and low education levels and in both blue and white collar jobs. The differential retention effect was especially marked for workers with tertiary education. In econometric analysis using macroeconomic data, the Bundesbank (2006) reported that outward German FDI is associated with increased domestic investment and positive employment effects.

Reflecting the success of private sector restructuring was the behaviour of profitability in German industry and the performance of the tradeables sector. The profitability of German firms improved and this is illustrated in the national accounts data where the net

\footnotetext{
${ }^{3}$ The corresponding figures for France are a fall in the share held by non-financial companies from $29 \%$ to $16 \%$ and a rise in the share held by financial institutions from $25 \%$ to $40 \%$ (Carlin, 2007).
} 
profit share staged a very impressive recovery (Fig. 1). The deep disruption to the private sector of the German economy caused by unification was overcome. The recovery since the mid 1990s contrasts with that in the 1980s. In the earlier episode, the recovery in business profitability was driven by the non-manufacturing sector whereas following its collapse after unification, the profit share in manufacturing has increased to levels recorded in the late 1980s boom. This is likely in part to reflect the greater opportunities afforded by outsourcing in the more recent period.

Figure 1. Long-run Behaviour of Net Profit Shares (NPS) in the Business Sector and in Manufacturing, Germany 1950-2005 (percent)

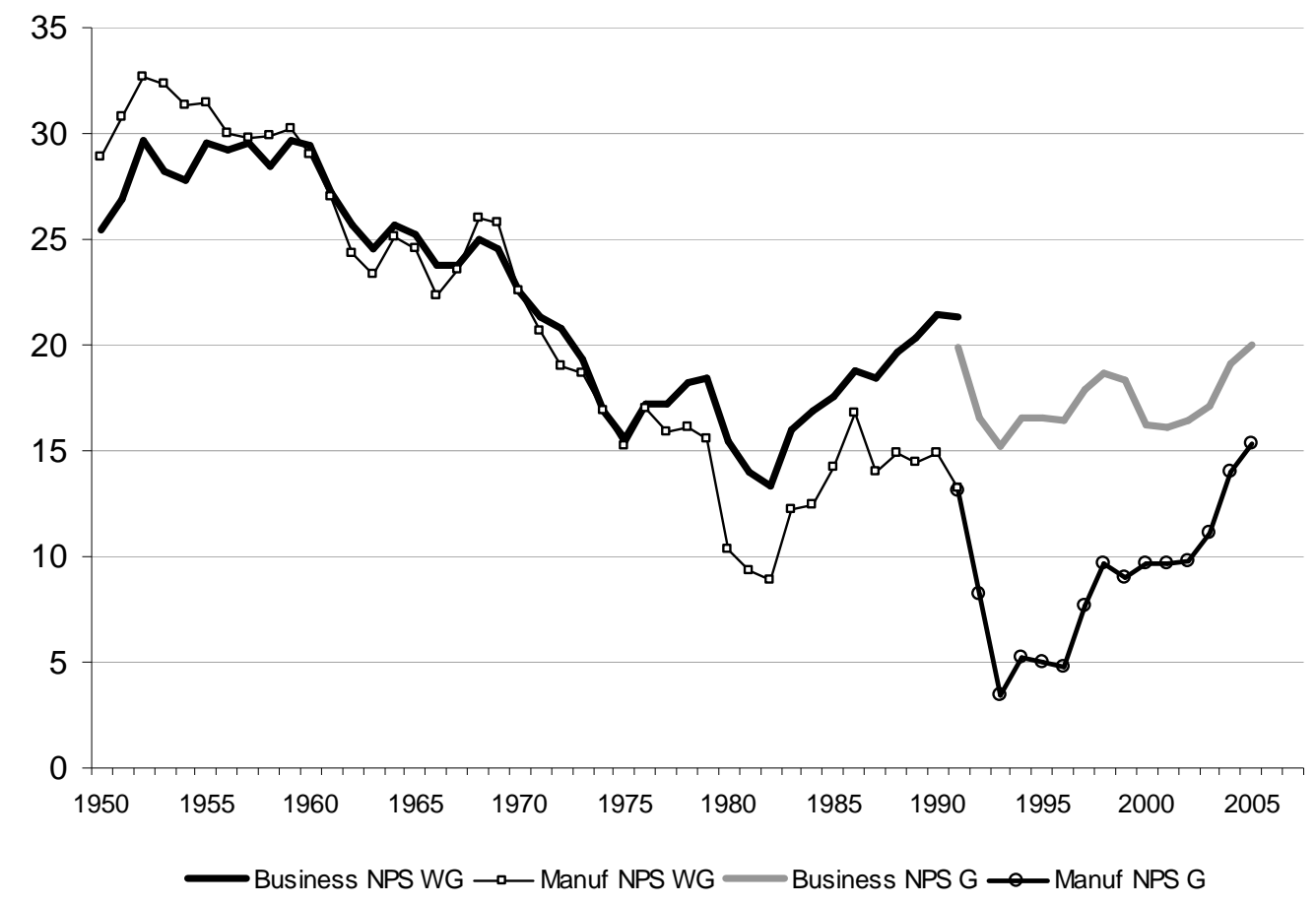

Source: Calculated from Statistisches Bundesamt (2008). Corrected for self-employment. The business sector is private, non-agricultural business excluding the rental sector.

Notes: The data from 1991 refer to unified Germany. However, the break in the series for the business sector is mainly accounted for by changes in national accounts methodology.

The success of restructuring from the mid 1990s is reflected in German export performance. During the period when China, India and the former communist countries of Central and Eastern Europe and the former Soviet Union entered world markets, the export performance of most OECD countries deteriorated. They lost market share to the new entrants. Germany's performance was counter to this trend: as Fig. 2 shows, Germany's export performance in goods and services improved over the decade to 2006 (See Fig. 2). In an econometric analysis of the determinants of export performance 20012004 in France, Germany, Italy and Spain, the authors conclude that 'Germany's relatively vibrant recent export performance is consistent with its comparative strength on 
price and cost competitiveness and global demand for its products' (Allard et al., $2005 \mathrm{p}$. 4). In contrast to the other countries there was also a positive growth of exports, unexplained by the traditional determinants of domestic and foreign demand and cost and price competitiveness. ${ }^{4}$

Figure 2. Export Performance of OECD Economics, 1995-2006

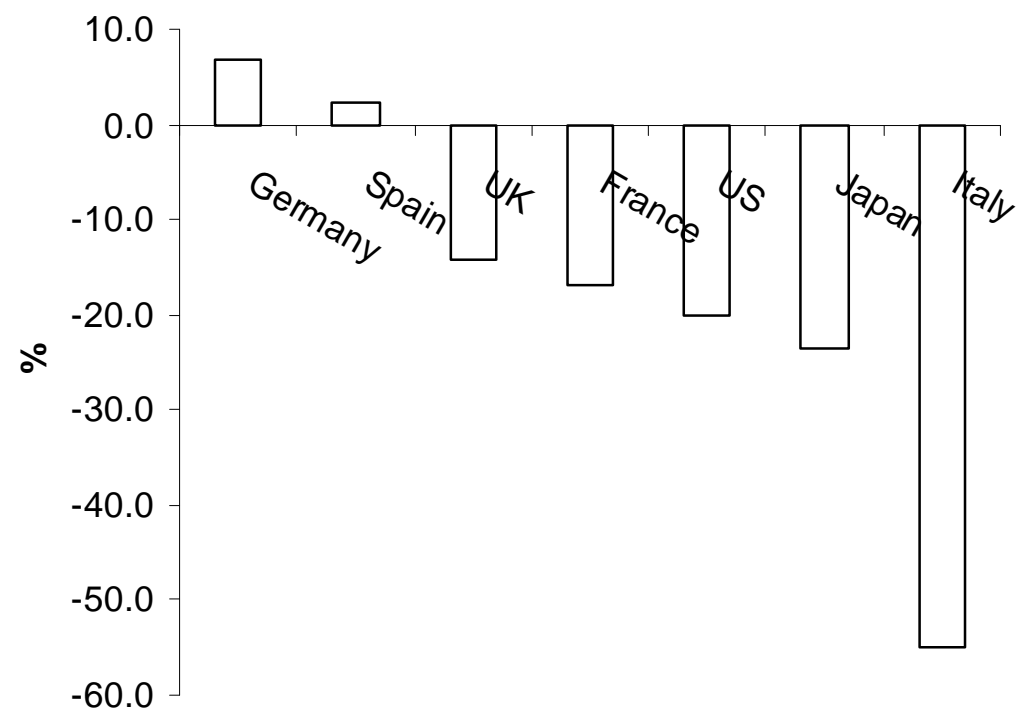

Source: OECD Economic Outlook 83 Annex Table 44.

Notes: This is the cumulated OECD measure of the change in export performance (export volume divided by total exports of goods and services).

\section{Supply-side restructuring - government labour market \& welfare state reforms}

The long period of high unemployment in Germany, which we argue in the next section was largely an aggregate demand phenomenon, prompted welfare state and labour market reforms of the traditional kind (beginning in the mid 1990s and culminating in the extensive Hartz reforms from 2003 onwards). Table 1 reports OECD data on the intensity of labour market and welfare state reforms undertaken, bench-marked against the OECD recommendations: Germany ranked fourth highest of thirty OECD countries in this measure of reform effort for the 1994-2004 period. The reform intensity of the UK during this period is shown for comparative purposes.

\footnotetext{
${ }^{4}$ This is consistent with the positive trend in export market share controlling for cost competitiveness for Germany identified by Carlin et al., (2001) for the earlier period, 1970-1992.
} 
Table 1 . The intensity of OECD-recommended labour market and welfare state reforms undertaken between 1994 and 2004

A.

$\begin{array}{lll} & \text { Overall score } & \text { Rank (out of 30 } \\ & & \text { OECD countries) } \\ \text { Germany } & 23.9 & 4 \\ \text { UK } & 16.7 & 11\end{array}$

B.

$\begin{array}{lllllll}\text { EPL } & \begin{array}{l}\text { Unemp. } \\ \text { Benefits }\end{array} & \begin{array}{l}\text { Working } \\ \text { time } \\ \text { flexibility }\end{array} & \begin{array}{l}\text { Early } \\ \text { Retirement }\end{array} & \begin{array}{l}\text { Wage } \\ \text { formation } \\ \&\end{array} & \text { ALMP } & \begin{array}{l}\text { Taxes } \\ \text { industrial }\end{array} \\ & & & & \begin{array}{l}\text { social } \\ \text { relations }\end{array} \\ & & & & \text { security } \\ 16.7 & 19.2 & 16.7 & 25.0 & 9.1 & 57.7 & 12.5 \\ -10.0 & 11.5 & 0.0 & 25.0 & -9.1 & 50.0 & 56.3\end{array}$

Source: Brandt et al., (2005). Table 8, p. 56.

Notes: The score relates to the number of actions taken. Measures introduced contrary to the recommendations of the OECD Jobs Study are scored with a negative number (e.g. the introduction of the minimum wage in the UK was scored negatively in 'Wage formation'). EPL - employment protection legislation; ALMP - Active Labour Market Policies. More detail is available in the Appendix of Carlin and Soskice $(2007 \mathrm{a}, \mathrm{b})$.

Evidence from a number of data sources confirms that the incidence of low-paid work ${ }^{5}$ in Germany began to increase in the mid 1990s (Bosch and Kalina, 2008). For example, among full-time workers incidence began to rise from 1995 in West Germany (after declining from 1980-1993). By 2003, 17.3\% of full-time employees in West Germany and nearly one-fifth in East Germany received less than two-thirds of West (resp. East) German median earnings. Internationally comparative data in a 6-country study show the incidence of low pay in 2005 varying widely from $8.5 \%$ in Denmark and $11.2 \%$ in France to $17.6 \%$ in the Netherlands, $21.7 \%$ in the UK, $22.0 \%$ in Germany, and $25 \%$ in the US (Mason et al. 2008). ${ }^{6}$

One effect of the reforms has been to leave particular groups such as the low skilled, immigrants and East Germans outside the generous German welfare state, whilst employees in the core labour system are still relatively protected. Inequality at the bottom of the wage distribution increased as collective bargaining ceased to cover them (Dustmann et al., 2007), and household poverty has increased (Förster and Mira d'Ercole, 2005). At the same time it appears that the children of those in the outsider labour market may be increasingly excluded from entry to the core labour system via the vocational

\footnotetext{
5 'Low pay' is defined as gross hourly earnings below two-thirds of the median hourly wage for all employees.

${ }^{6}$ Updated to 2005 by Geoff Mason. If East and West Germany are treated together, the low pay incidence is $22.7 \%$.
} 
training system, an outcome reinforced by the worsening performance of children in the lowest secondary school track (Bosch and Kalina, 2008). Meanwhile, the core labour system was characterized by continuity in institutional arrangements combined with effective restructuring by private agents. Restructuring in the core economy and reforms affecting the outsider labour market combined to depress real wage growth. We turn in Section 2 to the relationship between the behaviour of real wages and unemployment.

\section{Aggregate demand and persistent unemployment}

According to standard New Keynesian macroeconomic models, a sustained fall in unemployment without inflationary consequences must reflect supply-side improvements either via reforms or as a consequence of unanticipated positive productivity shocks. Conversely, persistently rising unemployment without continuously falling inflation suggests a worsening of supply-side conditions. In such models, aggregate demand plays a passive role in accounting for longer term changes in unemployment. Since only the supply-side determined equilibrium rate of unemployment is sustainable, fluctuations in aggregate demand either account for temporary deviations of the economy from the equilibrium or track the path of the economy to a new equilibrium following a supply side shift. For example, if supply side conditions have deteriorated but the downward adjustment of private sector aggregate demand is sluggish, the macroeconomic policy reaction functions will respond to the upward pressure on inflation and signal the necessary policy change to ensure stabilization of aggregate demand around a new higher unemployment equilibrium.

There is a sharp contrast between British and German economic performance in the period following the unification shock in Germany and the UK's exit from the Exchange Rate Mechanism. The British economy grew on average by more than one percentage point per year faster than Germany, its unemployment rate declined more or less continuously and its public debt shrank. German unemployment and public debt rose. The standard macroeconomic framework suggests that these differences reflect supplyside phenomena. However, Section 1 presented a prima facie case for the presence of supply-side improvements in Germany over this period: restructuring by the private sector of the export-oriented part of the economy, encapsulated by the recovery of profitability, together with the implementation of prescribed supply-side reforms. Indeed, applying the results of widely cited cross-country empirical studies of the determinants of cross-country unemployment performance to Germany (e.g. the panel data analysis of Bassanini and Duval, 2006) predicts that German unemployment should have fallen, not risen over this period. The Bassanini-Duval results predict a fall in unemployment in Germany of $1.6 \%$ points from 1993-2003 due to supply-side changes, when unemployment increased by $1.4 \%$ points; for the UK, one-half of the actual fall was predicted by supply-side changes. ${ }^{7}$

\footnotetext{
${ }^{7}$ Using the base-line linear regression in Bassanini and Duval (2006) and ignoring the variables with insignificant coefficients (union density and employment protection legislation).
} 
In this section, we point to three mechanisms through which the aggregate demand-side may help to account for the contrasting performance of Germany and the UK over the last decade. The first relates to the impact of aggregate demand shocks on the real exchange rate; the second focuses on the way that specific labour market institutions characteristic of Germany may interact with reforms to raise precautionary savings; and the third explores how wage restraint arising from the private sector restructuring and government reforms detailed in Section 1 may depress aggregate demand in a large economy.

\section{Long-lasting aggregate demand effects in the open economy}

One response to the ostensible failure of the standard New Keynesian model to explain the performance of the UK and Germany, is to extend the model to allow for long-lasting aggregate demand effects. This can be done by opening the economy and allowing for a causal effect of aggregate demand shocks on the real exchange rate and hence on medium-run unemployment. Central to the standard model is a negative relationship between the unemployment rate and the real consumption wage reflecting the behaviour of wage-setters. From the perspective of wage-setters, a lower unemployment rate is consistent with stable inflation only when the real wage is higher (given the disutility of work). However, from the perspective of price-setters, a higher real wage is not compatible with an expansion of employment: for example, assuming constant productivity, price-setters require an unchanged real wage to deliver their required profit margin at higher employment. Thus the constant inflation rate of unemployment in the closed economy is completely pinned down by supply side conditions. However in an open economy, the resources to make a higher real consumption real wage at lower unemployment compatible with an unchanged real product wage are potentially available from abroad through an appreciation of the real exchange rate. This lowers the real cost of imported goods and thereby boosts real consumption wages.

The next step in the argument is to connect shifts in aggregate demand to changes in the real exchange rate and the real wage. The open economy model assumes that firms produce differentiated goods that are sold in imperfectly competitive markets. Fig. 3 illustrates the case of an adverse aggregate demand shock. A lower level of aggregate demand reduces domestic output and raises unemployment (the move from point $A$ to point $\left.B^{\prime}\right)$. As a result, wage inflation falls relative to world inflation, the real exchange rate depreciates, worsening the terms of trade, and real consumption wages fall (point B). The higher real cost of imports allows a lower real consumption wage to prevail at a supply-side equilibrium with lower output and higher unemployment. ${ }^{8}$ Therefore shifts in aggregate demand, if they are persistent, can move the economy to new constant inflation unemployment rates. If there is a period of sustained weakness in aggregate demand, unemployment rises but inflation ceases to fall once real consumption wages have fallen to a level consistent with wage-setters' behaviour at higher unemployment (point B in Fig. 3). Conversely, in the case of a positive aggregate demand shock, in the open economy the closed economy mechanism through which rising inflation at lower unemployment leads the central bank to raise the interest rate and induce contraction

\footnotetext{
${ }^{8}$ This mechanism is described in Carlin and Soskice (1990, 2006), Layard et al., (1991) and is also found in new open economy models such as Corsetti and Pesenti (2005) and Gali and Monacelli (2005).
} 
back to the original unemployment rate is circumvented by the fact that real consumption wages can rise.

Figure 3. Open Economy Model: Adverse Demand Shock

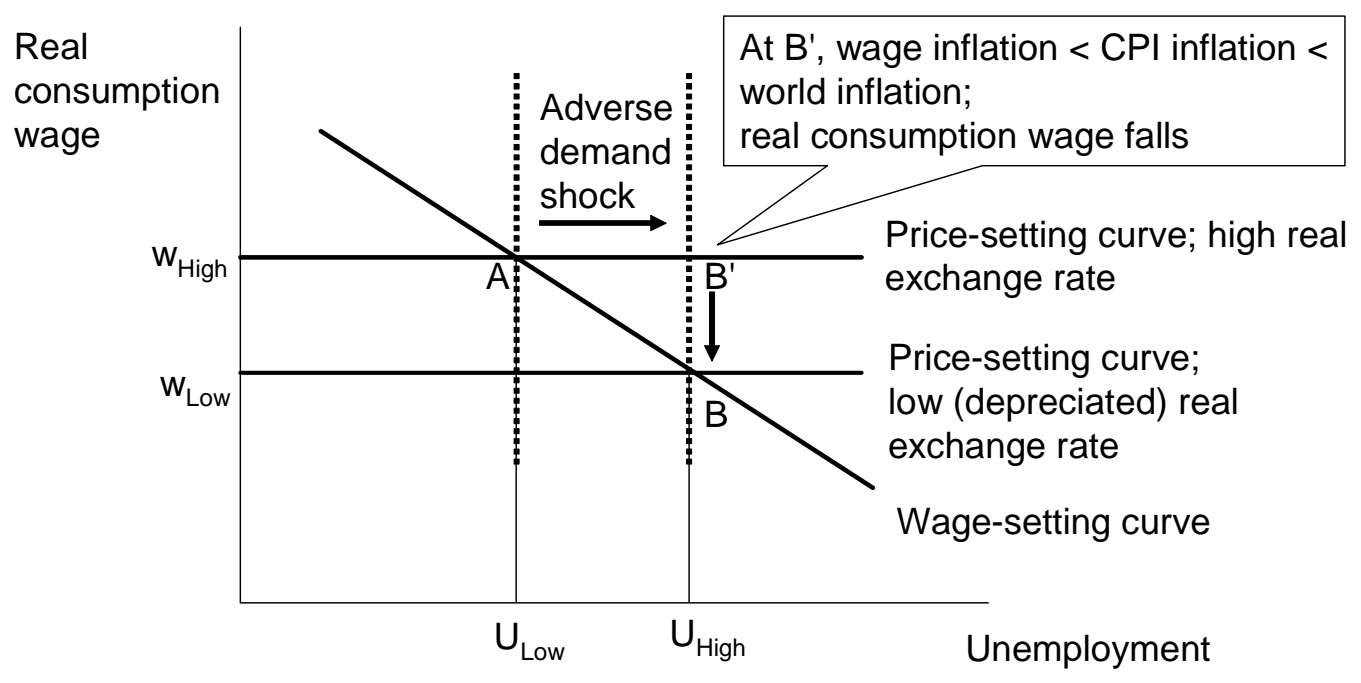

This argument stresses that shifts in aggregate demand can cause changes in the real exchange rate and hence in the constant inflation unemployment rate, rather than assuming them to be exogenous shocks as in much of the empirical literature that estimates NAIRUs (e.g. Batini and Greenslade, 2006 for the UK and Fitzenberger et al., 2007 for Germany). Estimates of time-varying constant inflation unemployment rates for the UK suggest that the appreciation of sterling and associated fall in real import prices from 1997 allowed unemployment to fall below the long term NAIRU (defined as the constant inflation unemployment rate determined solely by the supply-side) without accompanying inflationary pressure: "there was a lot of running room for unemployment to decline before giving rise to inflationary pressures" (Batini and Greenslade, 2006, p. 39). For Germany, Fitzenberger et al. (2007) estimate a time-varying NAIRU and find no evidence that it increased after the early 1990s. In accord with Batini and Greenslade, they report a significant effect on the NAIRU of the price wedge between the CPI and GDP deflators.

Fig. 4 presents data for the UK and Germany for the period from 1993. The left hand chart shows unemployment and CPI inflation performance: the limited difference between the countries in inflation and the contrast in unemployment are clear. The right hand chart provides data on labour productivity and real wage growth. After 1995, real wage growth in terms of consumer prices in the two countries diverges dramatically: 
rising in the UK and falling in Germany. Productivity growth differences are much more muted: German productivity growth is always above real wage growth, whereas the opposite is the case for the UK from 1996.

Figure 4. Comparative data for Germany and the UK: Unemployment, Inflation, Real Wage and Productivity Growth

A. Unemployment and Inflation (CPI)

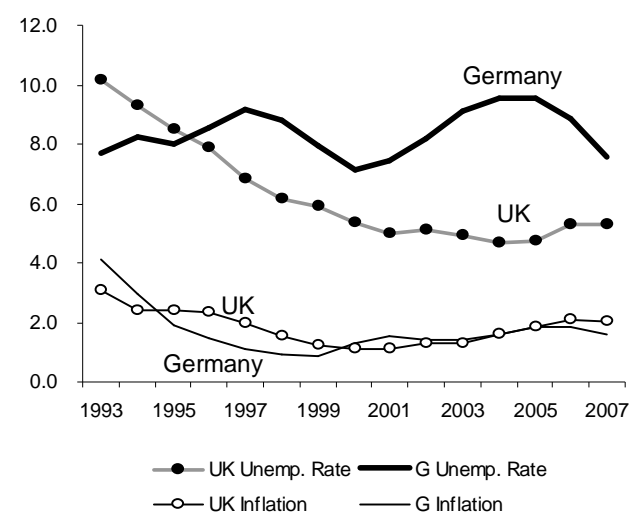

B. Real Wages and Productivity

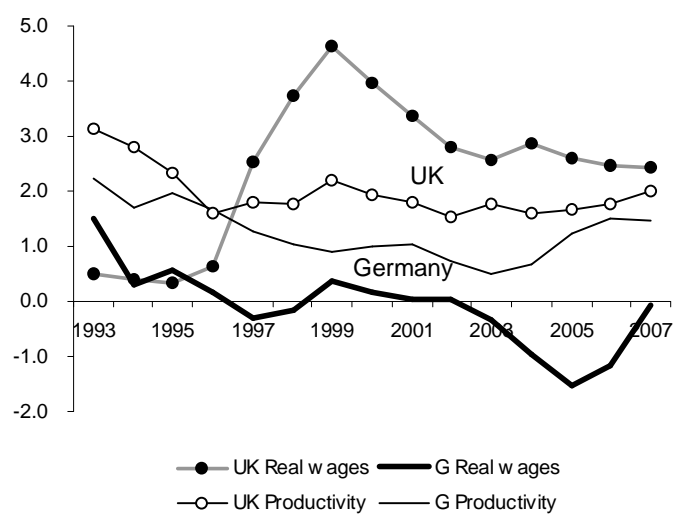

Source: OECD Economic Outlook Database, 82.

Notes: Unemployment is the OECD standardized rate (\%); Inflation is CPI (\% p.a.); Real wage growth is compensation per employee in the private sector deflated by the CPI (\% p.a.); Productivity is labour productivity (employment basis) (\% p.a.). Inflation, real wage and productivity growth series are 3-year moving averages.

We turn now to examine whether the evolution of real exchange rates was consistent with shifts in aggregate demand in these economies having played a major role in accounting for the behaviour of unemployment. In the case of Germany, the left hand panel of Fig. 5 shows higher unemployment associated with a depreciating real exchange rate, as would be the case in the face of negative aggregate demand shocks. By contrast, a boom in aggregate demand in the UK is consistent with the pattern in the right hand panel: falling unemployment and an appreciating real exchange rate. A movement from the south-east to the north-west in the chart is consistent with stronger aggregate demand (at a given real exchange rate) permitting a lower unemployment rate to be maintained because of the associated rise in the real wage. An important difference between the UK and Germany is that the sterling exchange rate was floating throughout. Hence part of the British adjustment took place rapidly through nominal appreciation around 1997 whereas real exchange rate adjustment in the German case (depreciation) took place in a more protracted fashion via domestic wage restraint (Fig. 4). By calculating the impact of the 
cumulative change in the terms of trade ${ }^{9}$, we find that whereas for the UK, a terms of trade gain occurred in both periods (6\% of GDP in the 1994-1999 period and 3\% in the 2000-2006 period), in Germany there was a gain, although less than one-third that of the UK, in the first period, but a loss of $1.3 \%$ of GDP in the second. Both countries - along with the rest of the OECD - benefited from the underlying trend of falling prices of imports from China throughout this period and suffered from rising oil and commodity prices from 2004.

Figure 5. Unemployment and the Real Exchange Rate, Germany and the UK, 1995-2006

Germany

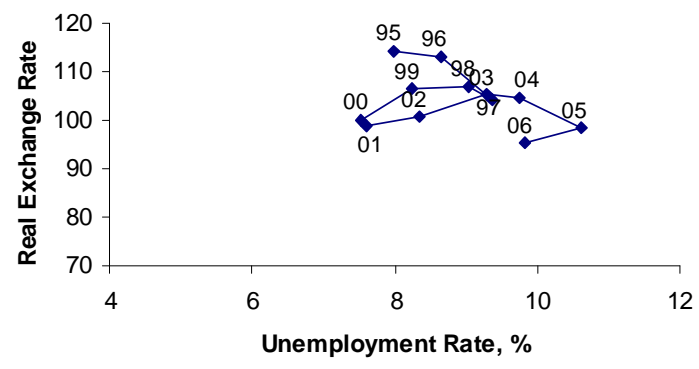

UK

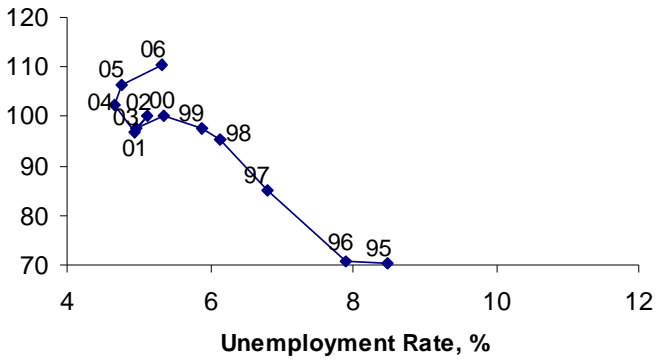

Source: OECD Economic Outlook Database 82.

Notes: The real exchange rate is an index of relative unit labour costs in manufacturing; $2000=100$; a rise in the index shows a real appreciation. The unemployment rate is the OECD standardized unemployment rate.

Although they can be regarded only as providing indirect evidence, the ex post patterns of aggregate demand in the UK and Germany are consistent with demand shocks playing an independent role in the evolution of unemployment in the two countries. Fig. 6 shows the ex post accounting contributions to the growth of real GDP of household consumption and housing; private investment; government consumption and investment; and net exports.

\footnotetext{
${ }^{9}$ The impact of the terms of trade is measured by multiplying the share of imports in GDP (M/Y, where M is Imports of Goods and Services in nominal terms and Y is GDP in nominal terms) by the change in the import price deflator relative to the GDP deflator. Source: Calculations using data from OECD Economic Outlook 82 Annex Tables and OECD National Accounts Database.
} 
Figure 6. Comparison between Germany and the UK in contributions to growth of aggregate demand, 1993-2005 (3 year moving average)
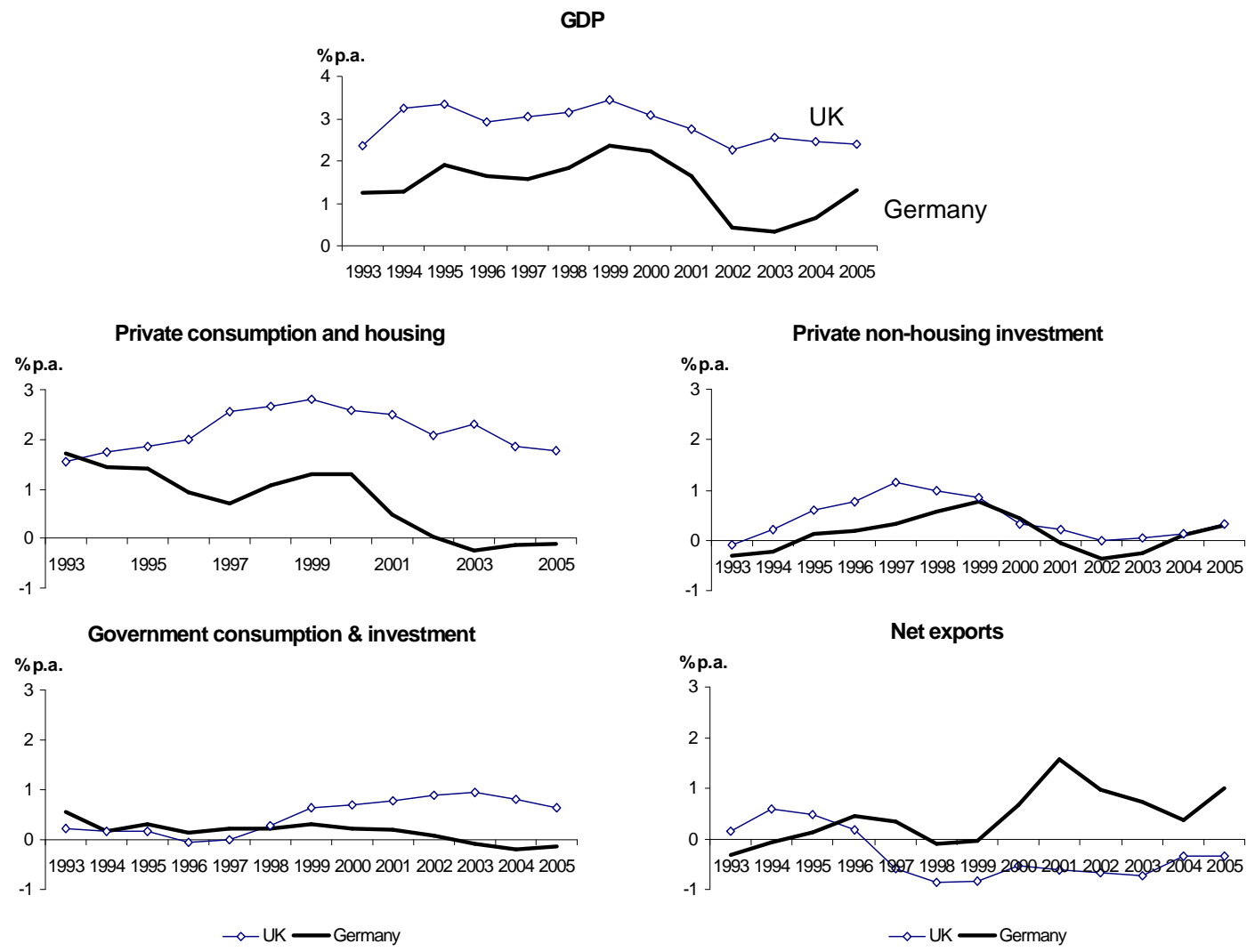

Source: OECD National Accounts Database June 2006

Notes: Contributions to the growth of constant price GDP (3 year moving average). The contributions do not add up to GDP growth because of the omission of stock-building, a statistical discrepancy and the treatment of government investment in housing.

The superior growth performance of the UK throughout is illustrated in the top chart. In the early years, British net exports and investment benefited briefly from the depreciation of the pound that followed sterling's exit from the ERM. However, this was soon replaced by a boom in private consumption and housing, which contributed about $2 \%$ p.a. to GDP growth throughout the period. In the second half, the growth of demand was sustained by strong public spending. This pattern contrasts sharply with the German one, where the contribution of private consumption and housing expenditure and government spending declined throughout the period. Growth in the 2000s was virtually entirely dependent on net exports. These contrasting patterns are more difficult to reconcile with a hypothesis highlighting supply-side problems in Germany: in that case, a given level of aggregate demand would be associated with upward inflationary pressure and a tendency toward a deterioration rather than improvement of net exports. 


\section{Interaction between German labour market characteristics and government reforms}

Although primarily directed at freeing up the outsider labour market, it is plausible that the government reform programme affected the behaviour of workers in the core labour system. Employees with specific skills can be expected to react with particular concern to a slowdown in growth, a rise in unemployment and the threat from welfare state reforms to unemployment benefits and pensions. For workers with specific skills it will generally be harder to find appropriate re-employment if they lose their jobs. Moreover, there is a negative externality in a labour market dominated by specific skills. If most of the work force has long-term employment, the number of vacancies within a given category of employment is likely to be limited; and companies may anyway seek to fill vacancies via apprenticeships. Thus mid-career labour markets for many categories may be quite 'illiquid'. ${ }^{10}$ The most obvious comparative example of this is with life-time employment in Japan: in the relevant categories, mid-career labour markets do not exist, short of accepting a position in a subsidiary company.

In Germany as in Japan, illiquidity of mid-career labour markets applies more to the relatively highly skilled - since firms have already invested more in them and, since it pays companies to invest more in them, they have longer tenure. Less skilled workers, but still with apprenticeship certificates, face more open occupational labour markets which are what portable qualifications should equip them to do. Given serious concerns about unemployment and with governmental pressure for welfare state reform in unemployment benefits and pensions, those with specific skills who remain employed in fact the great majority - would be expected to respond by supporting company-level pacts for employment and competitiveness described above and by building up precautionary and life-cycle savings. Iversen's (2005) analysis of the guarantor-insurance role of the welfare state for those with deep specific skills in a coordinated economy explains why this substantial proportion of the workforce should feel insecure as its welfare state benefits start to be questioned. Many employees factor in the possibility of involuntary early retirement or part-time work from their mid-50s should economic conditions become difficult - both schemes depend on welfare state provision. By contrast to liberal market economies such as the UK or US where a workforce with more general skills could imagine at a similar age responding to economic difficulty by finding alternative employment, labour markets for older workers do not exist on any substantial scale in Germany.

The German reform path did not entail the adoption of family policies that could potentially have improved the resilience of consumption by improving the incentives for women to participate fully in the labour market. The dramatic growth in the prevalence of marginal part-time jobs described in Section 1 has taken place in the context of a tax and

\footnotetext{
${ }^{10}$ Job tenure and job-finding rates differ sharply between Germany on the one hand, and the US and UK, on the other. $40 \%$ of workers have job tenure of more than ten years in Germany compared with $32 \%$ in the UK and $26 \%$ in the US. Estimated monthly average job-finding rates are 7.0 for Germany as compared with 11.3 in the UK and 56.3 in the US. By contrast, estimated monthly job-separation rates are quite similar at 1.06 in Germany, 1.53 in the UK and 1.06 in the US. (Hobijn and Sahin, 2007). In both the US and Germany there is lower job mobility for skilled than for unskilled workers but the differences in levels of mobility are striking: after ten years in the labour market, the average unskilled worker in Germany is in their $3.4^{\text {th }}$ job as compared with 2.8 for a skilled worker. The corresponding numbers for the US are 8.8 and 5.6 (Cornaglia, 2006).
} 
benefit regime in which spouses acquire access to social security via their husband and face a very high marginal tax rate if they exceed a limited number of hours of work. This structure undermines the development of a potentially important insurance mechanism within the household for families with risk-averse male workers who have specific skills.

In its review of the pro-cyclical behaviour of consumption in Germany from 2000, the Bundesbank noted the role of increased precautionary savings in response both to the worries about expected future income from the public pension system and to "widespread uncertainty about the effects of labour market reforms' (2007, p. 50). Giavazzi and McMahon (2008) used the natural experiment of the announcement by Chancellor Kohl in 1997 of a pension reform and its revocation a year later by Chancellor Schroeder to test for the effect of reform uncertainty on household behaviour. They found that uncertainty about reforms affecting the future path of incomes rather than reforms per se produced a significant rise in precautionary savings.

The left panel of Fig. 7 shows the evolution of the household savings ratio (as a percentage of disposable income) over the period in both countries. The pattern for Germany is a shallow U-shape, with the trough at the turn of the century. By contrast, there was a dramatic fall in the UK savings rate beginning around 1997. Unlike the US, where there was a sharp improvement in productivity growth from the mid 1990s (often attributed to the role of information technology), productivity growth in the UK remained stable and does not appear to offer an explanation for the decline of the savings rate. The role of house prices appears more relevant. Indeed, an important structural difference between the two economies over this period that is linked to consumption and savings behaviour is the evolution of house prices. ${ }^{11}$ House price trends in Germany and the UK have been opposite in the past decade: since 1995, real house prices in the UK have risen by an annual rate of more than $8 \%$ whereas they have fallen by more than $2 \%$ p.a. in Germany (partly due to the unwinding of the unification construction boom). The right hand panel of Fig. 7 illustrates the divergent behaviour of the house price to income ratio in the two countries. This difference helped sustain domestic aggregate demand in the UK and depress it in Germany. Although a house price bubble eventually bursts, the British experience suggests that it can contribute to sustaining buoyant growth over a considerable period.

\footnotetext{
${ }^{11}$ For cross-country empirical evidence demonstrating that there is a strong contemporaneous relationship between consumption and housing market wealth, see Case et al., 2005. Their study also reports that the impact of changes in housing wealth on consumption is larger and more important than of changes in stock market wealth.
} 
Figure 7. Household savings ratio and house price to income ratios, UK and Germany

Household savings ratio 1992-2006, percent

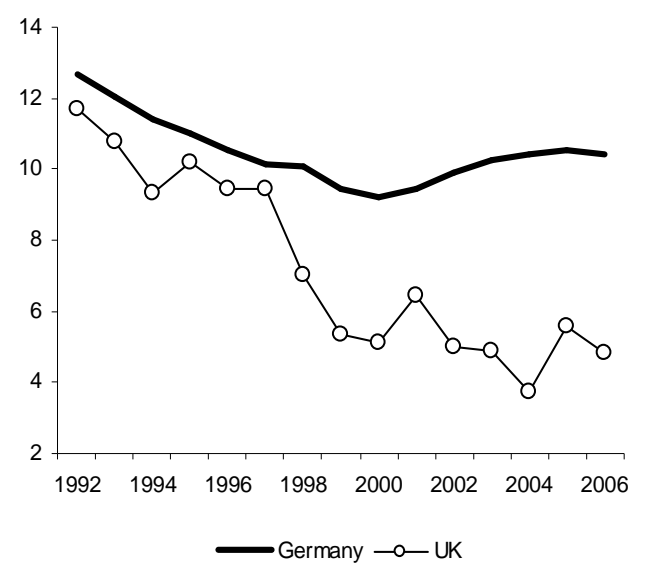

House price to income ratio 1995-2006, $(100=$ long-term average $)$

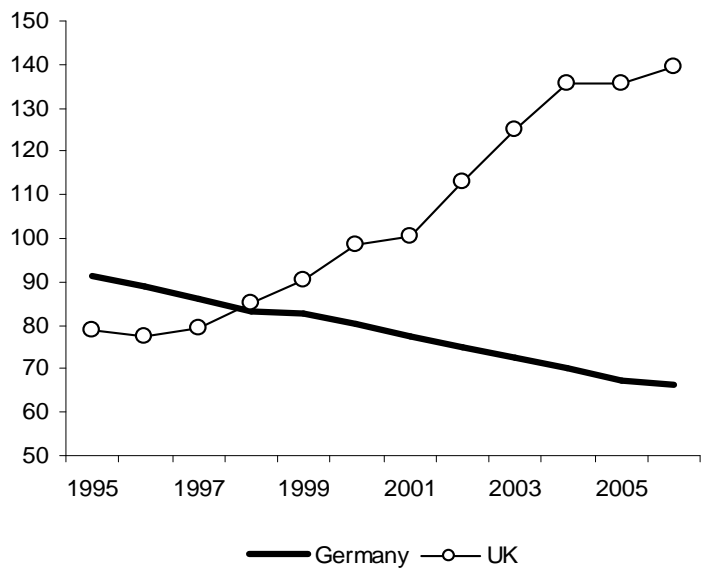

Source: Household savings ratio, OECD Economic Outlook 83 Annex Table 23; House price to income ratio, OECD Economic Outlook 83 Annex Table 60.

Supply-side reforms and aggregate demand: the large economy effect

The third mechanism suggesting a role for aggregate demand in accounting for Germany's poor performance focuses on the implications of supply-side reforms for a large economy. Section 1 argued that the combined impact of private sector restructuring and government reforms produced more restrained wage-setting behaviour (at a given unemployment rate). This can be depicted in Fig. 8 as a leftward shift of the wage-setting curve. However, the implications of this for unemployment depend on the balance between the impact of lower real wages (improved competitiveness) on net exports and investment (via improved profitability) on the one hand, and its depressing effect on consumption on the other. This balance will be affected by the size of the economy. For a small open economy, reforms that produce a real depreciation will reduce equilibrium unemployment ( $\mathrm{A}$ to $\mathrm{C}$ ), whereas for a large economy, the impact on consumption may outweigh that on net exports, producing a higher level of equilibrium unemployment at D. 
Figure 8. Supply-side Reforms: Large and Small-Economy Effects

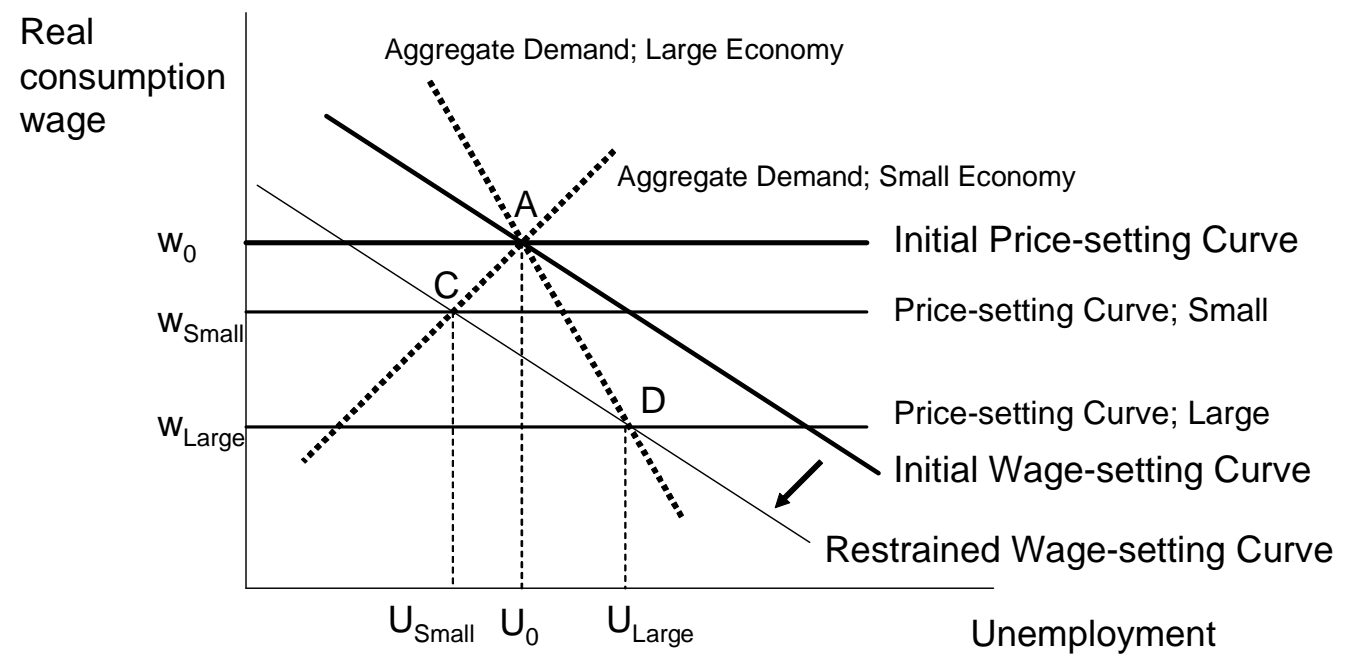

\section{Summing up}

We argued in this section that strong British and weak German economic growth and unemployment outcomes in the period since the mid-1990s are not well accounted for by an entirely supply-side hypothesis. We have suggested that in the open economy the presumption that performance over a decade or more must reflect supply-side conditions is mitigated by the endogenous response of the real exchange rate to shifts in aggregate demand and by the interaction between supply-side improvements and aggregate demand in a large economy. A positive aggregate demand shock will tend to produce a real appreciation, which permits the real wage to rise and a higher level of employment to be supported and similarly, a negative shock leads to a real depreciation, which reduces the real wage and eliminates falling inflation at higher unemployment. We have shown that contrasting patterns of aggregate demand and real exchange rates in Germany and the UK are consistent with a hypothesis in which aggregate demand shocks are important in accounting for the respective performance outcomes.

If anything, given the characteristics of its labour market, the implementation and announcement of supply-side reforms in Germany may have had the unintended consequence of raising precautionary savings in the core work-force as self-insurance substituted for expected lower state insurance reinforcing the depressed level of domestic aggregate demand. In the UK there is no core labour market where workers are involved with firms in making co-specific investments. Job turnover is higher in the UK and labour market reforms raising the cost of job loss do not affect expectations of life-time income in the same way as in Germany. It is also likely that whilst real wage restraint in Germany played a role in boosting net exports, its wider effects on aggregate demand in a large fairly closed economy reinforced the weakness of consumption by keeping real income growth low (European Commission, 2006, p. 200, Horn et al., 2008). Country economic performance may be affected for quite lengthy periods through the aggregate 
demand mechanisms described above. To the extent that these patterns are sustained by the build-up of underlying imbalances (e.g. a housing price bubble supporting a rate of household savings that is lower than the long-run equilibrium or an unsustainable deterioration of the current account), reversal will eventually take place.

A widely cited study published by the European Commission (2002) argued that twothirds of the shortfall in German growth relative to the rest of the EU in the 1995-2001 period was attributable to aggregate demand shocks associated with the after-effects of unification. The remainder was 'unexplained' and attributed to structural weaknesses in the labour market. A more recent Commission modelling exercise (of eurozone countries) using a simulated dynamic stochastic general equilibrium model, reported that ad hoc demand shocks had to be introduced to match the data for Germany in the post 2000 period. The authors note that "no particular shock is given to the labour market. The demand shocks, especially housing and corporate investment are sufficient to generate a decline in the employment rate of the same order of magnitude as observed in the data' (European Commission, 2006, p. 203). Although both of these studies emphasize the role of aggregate demand, the associated policy discussion stresses the importance of further conventional supply-side reforms. In the next section we suggest possible explanations for the absence of activist macroeconomic policy intervention in Germany.

\section{Political economic puzzles}

\section{Stabilizing macroeconomic policy and coordinated economy institutions}

If private sector demand shocks were an important source of the difference in macroeconomic performance between Germany and the UK, the question remains as to why stabilizing policy was not implemented in Germany. Macroeconomic policy was activist and stabilizing in the UK - making use of both monetary and fiscal policy instruments to sustain non-inflationary growth. By contrast in Germany from 1999, the ECB could react only partially to below target German inflation. Moreover, since inflation in Germany was below the eurozone average, Germany faced a higher real interest rate during a period of growth below the eurozone average. This places more weight on the role of fiscal policy. Although attempting to meet the $3 \%$ deficit limit of the Stability and Growth Pact imparted a pro-cyclical impact to fiscal policy exacerbated by the weakness of GDP growth, we argue in this section that fiscal activism in Germany may have been constrained for domestic political economy reasons - by the need to sustain incentives for wage restraint by the large wage-setters and by the exigencies of coalition government.

There is some evidence that countries divide into groups according to whether activist stabilizing fiscal policy is observed (e.g. OECD Economic Outlook 79, 2006, p.32). The OECD reports that countercyclical fiscal policy is observed in the 'other OECD' group, which includes the Anglo-American economies, and in the small Nordic economies with consensual wage-setting institutions. It is absent in the big continental economies with large but non-encompassing wage-setters. A study of the cyclicality of public consumption and its components for six OECD countries and the eurozone found that Germany showed the strongest pro-cyclical behaviour and that this was more pronounced for the series capturing policy-induced dynamics (Lamo et al., 2007). Similar but less 
pronounced pro-cyclicality was found for Italy, Spain and France. More mixed results and some evidence of counter-cyclicality was found for the UK, US, Sweden, Denmark and Japan.

From a political economy point of view there are two institutional situations that may lead to the creation of a conservative framework for the operation of fiscal policy ruling out the possibility of the use of discretionary fiscal policy (except perhaps in extreme circumstances, as eventually in Japan). The first situation is where there are a limited number of powerful wage bargainers who set the inflation rate and de facto the real exchange rate; we shall refer to this as the Small-N case. These powerful unions, usually in industrial sectors but also in the public sector, themselves represent a spectrum ranging from core highly skilled members in no danger of losing their jobs even with sizeable real wage increases to more substitutable employees in more marginally profitable companies or industries. If we assume these unions were acting independently (only partly true), and that the government was pursuing a discretionary fiscal policy to respond to increased unemployment, then each union is big enough to believe that an increase in unemployment as a result of its own actions will lead to some offsetting response by the government of the order of $1 / \mathrm{N}$. By abandoning discretionary fiscal policy and therefore removing this possibility, the government sharpens the incentives for wage moderation. ${ }^{12}$

This analysis appears relevant to Germany. The coordination of wage bargaining that we observe in Germany is an ex-post phenomenon reflecting the understanding of the major unions that any one of them is in a position to gain serious real wage increases and in turn that this would put pressure on other unions to be more aggressive. Given the fear of sharp conservative responses to inflation this has led to concerns across the major unions and produced the outcome of coordinated restraint. Under EMU where the threat from the Bundesbank to punish excessive wage settlements was no longer present, the implication is that tougher fiscal policy is required.

Note that the prospect of discretionary fiscal policy has no effect when labour markets are flexible, or if there are a great many independent bargaining units, since no wage-setter believes that the tiny increase in unemployment resulting from its own wage bargain will change government expenditure. So neither the UK nor the US with flexible labour markets should fear the effect of discretionary fiscal policy. Equally, countries such as the Nordic ones with encompassing wage bargainers, or countries in which all the relevant wage bargainers sit around a table with the government and make a binding wage contract should be happy to conduct a flexible fiscal policy. In each of the latter cases, the macroeconomic implications of the wage bargain are internalized in the wagesetting process itself. By contrast in the German (or more generally, small-N case) where behaviour is non-cooperative, coordinated wage restraint is elicited by the presence of a non-accommodating macroeconomic framework. The classification (e.g. by the OECD) of Nordic countries and Germany as 'high corporatism' or 'high coordination' reflects two distinct sets of institutions, only the latter of which requires associated nondiscretionary fiscal policy.

Second, the structure of governments may affect the incentives for running a discretionary fiscal policy (Hallerberg et al., 2001). The basic argument is this: coalition

${ }^{12}$ Analogous results hold for monetary policy, see Soskice and Iversen (2000). 
government leads to a common pool problem if individual ministries with presumably different party preference functions can independently decide on expenditure while taxation is general. Expenditure will be too high with coalition government. Thus it will be in the interest of all the members of the coalition to work out a binding contract regarding how much each ministry (or party) should be allowed to spend. For the binding contract to work there needs to be a tough fiscal framework. This is likely to be at odds with a discretionary approach since there is a principal agent problem: whichever agent (say the Minister of Finance) is put in charge of the discretion will incite the concern of the principal (the other coalition members) that it is being used to the advantage of the Finance Minister's party. Hence coalition governments will be nervous about discretionary fiscal policy. Coalition versus single party government is largely a product of the electoral system. Majoritarian systems nearly always produce single party government; proportional representation systems nearly always produce coalitions (or, what are de facto the same, minority governments with agreed support from other parties).

\section{Consensual political systems and the nature of reforms}

We noted earlier that coordinated economies have consensus political systems. They are characterised by proportional representation, coalition government, strong opposition committee rights and representative parties in which policy positions get negotiated out between different interests within the party. Thus different groups are well-entrenched politically in these systems, and it takes something like super majorities to bring about major changes in their droits acquis. These systems also normally produce centre-left coalitions - put crudely because centre parties can do better allying with left or centre-left parties and taking resources from higher income groups than they can allying with right of centre parties and taking resources from low income groups (Iversen and Soskice, 2006a). So in principle low income groups are well-represented politically in coordinated economies, both because of the general protection of the political system against arbitrary or rapid change and because of the particular partisan colour of governments. The contrast with the lack of protection that the political system in the UK gives to low income groups is marked: a preponderance of centre-right governments, a leadershipdominated Labour Party necessarily focussed on the middle classes and its preoccupations - toughness on crime and good education for their children - to win plurality elections, and the almost complete absence of power of the opposition or other groups in parliament.

Given the features of consensus political systems, it remains to be explained how orthodox labour market and welfare state reforms that widen the income distribution gained political support in Germany and why alternative reforms along Nordic lines were not adopted. For example, the German authorities did not develop a serious, quasi compulsory cross-sectoral retraining programme to provide the skills for those made redundant in industry (typically the less skilled) to be reemployed in services. Part of the explanation rests on the fact that unions and employer associations in Germany are sectorally based and the powerful industry organisations have little incentive to invest in retraining for services. Lower income groups outside industry have limited union representation, and thus there has been less pressure for devoting resources to their adequate retraining. By contrast in Scandinavia and Finland, there is more effective 
cooperation within the union movement across sectors. Nor did German policy-makers reform the education system, where children are separated into three different schooling tracks at a young age. This makes the acquisition of social skills, including the ability to communicate easily across classes, harder to acquire subsequently. In Scandinavia, students are at common secondary schools and where tracking occurs, it is much later (at age 16 rather than at 10 in Germany). As noted in Section 1, another Nordic reform route not taken in Germany relates to the reduction in the costs for women of moving between working at home and in the market. Among coordinated systems, across all of these dimensions, Germany is a thus a more fragmented society than those in Scandinavia and Finland.

The German political system fits the consensus description well, but it is exceptional among such systems in not having above average centre-left governments in the post second world war period. Manow and van Kersbergen explain this by arguing that a major Christian Democratic party with a strong social wing to counterbalance the interests of business has been more attractive to middle class voters than social democracy (Manow and van Kersbergen, 2007). The interests of low income groups were therefore represented in the social wing of the CDU, as indeed in the CSU, as well as in the Social Democratic party. Thus the political move to embrace flexible labour markets by weakening protective labour market institutions required an alliance shift that would, in effect, produce a super-majority that excluded low income workers and the unemployed.

Two broad sets of factors made this easier than it would have been in the Nordic countries: the relative fragmentation of unions and the nature of German political partisanship. Unions in Germany were divided both within and among themselves: works councils representing skilled workers had every interest in flexible low level service labour markets (even if not expressed openly) since it implied cheaper services and therefore increased the real income for their members, and it implied that their members would bear less of the cost of prolonged unemployment; unions directly representing low level service sector workers had much less weight than the major industrial unions; and the major industrial unions were split between the interests of powerful works councils and their own interest in catering for and protecting lower income workers in industry. And, pace Manow and van Kersbergen, faced with this major economic/distributional crisis, middle class voters in Germany were not pushed towards a centre-left solution that protected low income workers and the (typically low skilled) unemployed, because Christian democracy was weighted towards the centre and thus potentially offered an alternative solution; this pushed the SPD equally towards the centre if it was to compete with the CDU, and the fragmentation within and across the unions made this possible. The coalitional realignment was sealed by the fracturing of the left of the SPD and the formation of the Left Party.

There is of course a question as to whether this shift in political coalitions - the fracturing of social democracy and the similar displacement of the influence of the social wing of Christian democracy - is permanent or a temporary consequence of the lengthy period of 
poor macro-economic performance. Strong forces within both major political groupings are contesting this general shift in policy.

\section{Conclusions}

Although the central institutions associated with Germany's coordinated economy (vocational training, blockholder ownership, collective bargaining and codetermination) are still in place, their functioning is more flexible and less encompassing than it was earlier. In particular, two major and partially related changes are noticeable.

First, companies and their employees are less solidaristic than they were in relation to the wider organised business community and industry unions; they are more companycentred, or in Wolfgang Streeck's phrase 'betriebsegoistisch'. As Thelen (2007) has pointed out, this shift is reshaping the operation of the vocational training system. And, while corporate governance remains based on block shareholdings and capable of taking a long term perspective, financial globalization has had an influence, with the concomitant rise of foreign - typically minority - share-holders. Thus our analysis has suggested that the advanced sectors of the German economy have restructured using private sector coordinating institutions, which is far from inconsistent with the coalignment of management and employee interests with the long-term profitability of the company. In these respects, we may be seeing a shift in the balance of power, common to all coordinated economies, away from encompassing labour organizations toward coordinated company- and sector-based coalitions pushed by financial globalization.

Second, as far as the bottom end of the labour market is concerned, Germany has developed somewhat differently from most other coordinated economies. Here there has been a conscious effort by the German government to create a flexible market for low skilled workers in an effort to cope with rising unemployment among this group. While flexible labour markets exist to some extent at the bottom end of most countries classified as coordinated economies, the phenomenon is especially marked in Germany (Rueda and King, 2008). This is reflected in a worsening of the income distribution and growing incidence of low-wage work. While inequality has not reached American or British levels our analysis suggests that care is needed in identifying coordinated economies with egalitarian outcomes.

What has caused this development? A major point of this paper is that one cannot analyse structural change in economies without bringing in macroeconomics. Macroeconomics was central to comparative political economy in the 1970s and 1980s: it was essential in the analysis of the OPEC and other deflationary shocks of the 1970s, with sharp distinctions between corporatist and other economies in the nature of macroeconomic responses. Given the variety of macroeconomic shocks over the past decade and a half from country-specific shocks such as German unification and its aftermath, and houseprice based consumer booms, to the differential country impact of the formation of the eurozone and of the growth of the emerging economies - somewhat paradoxically, the macroeconomic dimension has dropped out of the comparative political economy repertoire (Iversen \& Soskice, 2006b). 
Our argument suggests that macroeconomic factors played a key role in accounting for the differential impact of macroeconomic shocks on the Germany economy as compared with other coordinated economies. First, unlike other coordinated economies (with the notable exception of Japan), Germany is large. Wage restraint is therefore likely to have exacerbated the weakness of German aggregate demand with the adverse effect of real wage cuts on consumer spending offsetting its beneficial effect via the external balance. Second, faced by a small number of powerful wage setters, the German fiscal authorities adopted a conservative rather than a discretionary fiscal stance. The government was not basically open to deals with unions over expenditure programmes. This contrasts not only with the discretionary fiscal stance adopted by liberal market economies with flexible labour markets such as the US and the UK (as illustrated in Section 2) but also with inter alia Nordic countries with encompassing wage setting arrangements for whom 'semicommitted' collective understandings with the unions were easier. The outcome (reinforced by the Stability and Growth Pact) was pro-cyclical fiscal policy in contrast with its counter-cyclical impact in the liberal and Nordic economies.

Thus initial negative shocks were magnified in one or both of two ways differently from other coordinated economies: wage restraint amplified the shock rather than dampening it; and fiscal policy tightened in order to hold down the deficit in public spending rather than allowing automatic stabilisers to work fully. In addition precautionary savings were built up at least in part in response to the concerns about cutbacks in the welfare state generated by government policy. Germany had to face a prolonged period of high unemployment and depressed growth with the associated heavy costs on the budget.

The analysis presented in this paper suggests that Germany remains a coordinated economy but, enabled by the reconfiguration of the underlying political coalition, a less egalitarian one. This has resulted from the combined impact of the restructuring carried out by firms in conjunction with the institutions of the coordinated economy in the core economy, the supply-side reforms introduced by the government, and the long period of depressed growth. The conventional analysis of German performance and reforms assumes that generic labour market reforms can only be beneficial and that barriers to their more rapid implementation are the consequence of vested interests or a lack of resolve of politicians. By contrast, our argument suggests firstly, that reform design in Germany is complicated by the continuing importance for its dynamism of the core sectors of the economy that rely on 'non-standard' institutions and second, that political opposition to reforms that weaken protective labour market institutions is less important than often assumed. 


\section{References}

Addison, J. T., Schnabel, C. and J.W. Wagner, (2007). 'The (parlous) state of German Unions', Journal of Labor Research. 28 (1)

Allard, C., Catalan, M., Everaert, L., and Sgherri, S. (2005). 'Explaining differences in external sector performance among large Euro area countries', IMF Working Paper.

Bassanini, A. and Duval, R. (2006). 'Employment patterns in OECD countries: reassessing the role of policies and institutions'. OECD Working Paper 486. (Also summarized in OECD Economic Policy 2006, Chapter 7.)

Batini, N. and Greenslade, J. (2006). 'Measuring the UK Short-Run NAIRU', Oxford Economic Papers. $58,28-49$.

Becker, S.O. and M-A. Muendler, (2008). 'The Effect of FDI on Job Security', The B.E. Journal of Economic Analysis and Policy Vol. 8 Iss. 1 (Advances), Article 8. Available at http://www.bepress.com/bejeap/vol8/iss1/art8

Bosch, G. and T. Kalina (2008). 'Low-wage work in Germany: An Overview' in Bosch and Weinkopf (ed) (2008).

Bosch, G. and Weinkopf, C. (ed.) (2008). Low-Wage Work in Germany. Russell Sage Foundation: New York.

Brandt, N., Burniaux, J-M and R. Duval (2005). 'Assessing the OECD Jobs strategy: Past developments and reforms'. OECD Working Paper, 429.

Carlin, W. (2007). 'Ownership, Corporate Governance, Specialization and Performance: Interpreting Recent Evidence for OECD Countries', Mimeo, Cournot Centre for Economic Studies, Conference Does Company Ownership Matter? Efficiency and Growth.

Carlin, W., Glyn, A., and Van Reenen, J. (2001). 'Export market performance of OECD countries: an empirical examination of the role of cost competitiveness' Economic Journal. Vol. 111, No. 468, 128-162.

Carlin, W. and Soskice, D. (1990). Macroeconomics and the Wage Bargain. OUP: Oxford.

Carlin, W. and Soskice, D. (2006). Macroeconomics: Imperfections, Institutions and Policies, OUP: Oxford.

Carlin, W. and Soskice, D. (2007a). 'Reformen, macroökonomische Politik under Wirtschaftsentwicklung Deutschland' in R. Schettkat und J. Langkau (Hrsg.) Aufschwung für Deutschland: Plädoyer international renommierter Ökonomen für eine neue Wirtschaftspolitik. Dietz: Bonn.

Carlin, W. and Soskice, D. (2007b). 'Reforms, Macroeconomic Policy and Economic Performance in Germany’. CEPR Discussion Paper No. 6415.

Case, K. E.; Quigley, J. M.; and Shiller, R. J. (2005) 'Comparing Wealth Effects: The Stock Market versus the Housing Market', Advances in Macroeconomics: Vol. 5 : Iss. 1, Article 1. Available at: http://www.bepress.com/bejm/advances/vol5/iss1/art1

Cornaglia, F. (2006). 'Mobility and Wages of Young Workers', PhD Thesis University of Turin. 
Corsetti, G., and Pesenti, P. (2005) 'Welfare and macroeconomic interdependence'. Quarterly Journal of Economics 116(2), 421-446.

Deutsche Bundesbank. (2006). 'German Foreign Direct Investment (FDI) Relationships: Recent Trends and Macroeconomic Effects', Monthly Report, September.

Deutsche Bundesbank. (2007). 'Private Consumption in Germany Since Reunification' Monthly Report, September.

Dustmann, C., Ludsteck, J. and U. Schönberg (2007). 'Revisiting the German wage structure'. Mimeo, UCL. .

European Commission (2002). 'Germany's Economic Performance in the 1990s', , European Economy Economic Paper, No. 170. Directorate General for Economic and Financial Affairs

European Commission (2006). 'Adjustment Dynamics in the Euro Area: Experiences and Challenges' European Economy Review 2006. Directorate General for Economic and Financial Affairs

Fitzenberger, B., Franz, W., and Bode, O. (2007). 'The Phillips Curve and NAIRU Revisited: New Estimates for Germany'. ZEW Discussion Paper NO. 07-070. Mannheim.

Förster, M. and Miro d'Ercole, M. (2005). 'Income Distribution and Poverty in OECD countries in the Second Half of the 1990s' OECD Social, Employment and Migration Working Paper No. 22.

Gali, J., and Monacelli, T.(2005) Monetary policy and exchange rate volatility in a small open economy. Review of Economics Studies 72 (2005), 707-734.

Giavazzi, F. and McMahon, M. (2008). 'Policy Uncertainty and Precautionary Savings'. CEP Discussion Paper No. 863.

Goyer, M. (2006) 'Varieties of institutional investors and National Models of Capitalism: The Transformation of Corporate Governance in France and Germany', Politics and Society Vol. 34, No. 3., 399-430.

Goyer, M. (2007). 'Institutional Investors in French and German Corporate Governance: The Transformation of Corporate Governance and the Stability of Coordination'. Center for European Studies Harvard WP 07.2.

Hall, P. A. and D. Soskice, Eds. (2001). Varieties of Capitalism: the Institutional Foundations of Comparative Advantage, Oxford University Press

Hallerberg, M., Strauch, R. and von Hagen, J. (2001). 'The Use and Effectiveness of Budgetary Rules and Norms in the EU States' Report for the Dutch Finance Ministry.

Hassel, A. and B. Rehder (2001). 'Institutional Change in the German Wage Bargaining System - The Role of Big Companies', MPIfG Working Paper 01/9, December.

Hobijn, G. and Şahin, A. (2007). 'Job-Finding and Separation Rates in the OECD', Federal Reserve Bank of New York Staff Reports, No. 298.

Höpner, M. (2003). Wer beherrscht die Unternehmen? Shareholder Value, Managerherrschaft und Mitbestimmung in Deutschland. Frankfurt a.M.: Campus.

Horn, G., C. Logeay and R. Zwiener (2008). 'Wer profitierte vom Aufschwung?', IMK Report Nr. 27, März 2008. 
Iversen, T. (2005). Capitalism, Democracy and Welfare. Cambridge, UK, Cambridge University Press.

Iversen, T and Soskice, D. (2006a), "Electoral Institutions, Parties and the Politics of Class: Why Some Democracies Distribute More than Others", American Political Science Review, May.

Iversen, T. and Soskice, D. (2006b) "Political Science and the New Macroeconomics", Annual Review of Political Science.

Lamo, A., Pérez, J. and Schuknecht, L. (2007). 'The Cyclicality of Consumption, Wages and Employment of the Public Sector in the Euro Area'. ECB Working Paper Series, No. 757.

Layard, R., Nickell, S. and R. Jackman (1991). Unemployment, Macroeconomic Performance and the Labour Market. Oxford: OUP.

Lloyd, C., Mason, G. and K. Mayhew (ed.) (2008), Low-Paid Work in the UK. Russell Sage Foundation: New York.

Manow, P. and K. van Kersbergen (2007). 'Religion and the Western Welfare State: the Theoretical Context' in K. van Kersbergen and P. Manow (ed.) Religion, Class Conflict and Welfare State Politics. (Book ms.)

Mason, G., Mayhew, K. and M. Osborne, (2008). 'Low-Paid Work in the UK', in Lloyd, Mason and Mayhew (ed). (2008).

Mason, G., O'Leary, B. and M. Vecchi (2007). 'Cross-country Analysis of Productivity and Skills at Sector Level', NIESR Report for Sector Skills Development Agency.

Mohrenweiser, J. and Zwick, T. (2008). 'Why do Firms Train Apprentices? The Net Cost Puzzle Reconsidered'. ZEW Discussion Paper No 09-019.

OECD (various years) Economic Outlook, Paris.

OECD (2008) OECD.Stat; Labour Force Statistics, 2008, Paris.

Rueda, D. and D. King, (2008). 'Cheap Labor: The New Politics of "Bread and Roses" in Industrial Democracies'. Perspectives on Politics, 6, pp279-297

Soskice, D. (1994). 'Reconciling markets and institutions: the German apprenticeship system' in Lisa M. Lynch (ed). (1994). Training and the private sector Chicago: University of Chicago press, pp. 2560.

Soskice, D. and Iversen, T. (2000) "The Non-neutrality of Monetary Policy with Large Wage and Price Setters", Quarterly Journal of Economics.

Statistisches Bundesamt (2008). Volkswirtschaftliche Gesamtrechnungen Inlandsproduktrechnung Detaillierte Jahresergebnisse 2007 Fachserie 18 Reihe 1.4, Wiesbaden.

Thelen, K.(2007). 'Contemporary Challenges to the German Vocational Training System', Regulation and Governance, 1, 247-260.

Vogel, S. (2006). Japan Remodeled. Ithaca, Cornell University Press. 